\title{
Empowerment Dynamics and Socio-economic Development: "Relevance to Women in Developing Societies"
}

\author{
Joseph Kwasi Brenyah \\ Centre for Social Policy Studies, University of Ghana, Ghana
}

Copyright $\mathrm{C} 2018$ by authors, all rights reserved. Authors agree that this article remains permanently open access under the terms of the Creative Commons Attribution License 4.0 International License

\begin{abstract}
Socio-economic vulnerability has gradually gained roots within societies due to inequalities. Most individuals are not able to defend their rights, particularly the poor. Many people with potential have not been able to take up opportunities in life due to a lack of empowerment. Empowering vulnerable groups such as women may be the best way to overcome circumstances such as poverty, poor educational opportunities and social exclusion tendencies. This study identified the various approaches to empowerment, ascertained the association between empowerment and some socio-economic aspects of human life. This study was a systematic review, underpinned by the Middle Range Theory of Community Empowerment. The study noted that, empowerment is not the power granted to an individual or group but rather the measures taken for a person to acquire knowledge, power and skills leading to change in a phenomena. The study revealed that, despite efforts in empowering individuals particularly, women, factors such as educational status, cultural and social factors, health systems and ineffective social protection intervention programmes inhibit the various empowerment processes. The study recommended the need to create fiscal space to fund social protection interventions, give up some outmoded social and cultural practices, and provide education especially for young women.
\end{abstract}

Keywords Empowerment, Dynamics, Socio-economic, Development, Women, Societies

\section{Introduction}

In recent times, the global discourse regarding socio-economic vulnerability is gradually gaining roots among policy makers. Due to inequality, people have not been able to defend their rights, particularly the poor.
Indeed poor people individually are powerless to influence or bargain for better trade benefits, negotiate for good financial terms, hold dialogue with governmental and non-governmental bodies and other fellow civilians. This behaviour is attributed to a lack of political, social, economic, cultural and environmental capacity. Many potentially abled persons have not been able to take up opportunities in life due to lack of empowerment. Empowering vulnerable groups such as women may be the best way to overcome circumstances such as poverty, poor educational opportunities and social exclusion tendencies.

There has been a noticeable growing debate on the definitions to the word "empowerment" across different disciplines. The contestations over the meaning of "empowerment" have been discussed both from the French and Latin orientations ${ }^{[1]}$. The writers have revealed that, the first recorded use of the word "empower" was noted in the $17^{\text {th }}$ century by Hamon L'Estrange in the book entitled The Reign of King Charles. Accordingly, the use of the word, empowering in that connotation was "sanctioning" and "certifying". Similarly, the Oxford English Dictionary defined "empowerment" as "the action of empowering; the state of being empowered" and this definition has been in force since 1849 . From the above dictionary definitions, the word "empowerment" is not power itself but is a process. Empowering a person is not giving power but taking the person or group through some measures in securing power ${ }^{[2]}$.

Corroborating the assertion of Lukes ${ }^{[2]}$, Solomon, acceded that, "Empowerment" is "the process whereby persons who belong to a stigmatised social category throughout their lives can be assisted to develop and increase skills in the exercise of interpersonal influence and the performance of valued social roles" ${ }^{[3]}$.

From another perspective, empowerment is a word that is used essentially to raise awareness ${ }^{[4,5]}$. Any time the word empowerment is used for a person or group; some immediate comparative words which come to mind about 
the persons or group are narrow authority, incapacity, powerless, vulnerable, indecisive, ignorance and the like. For instance, taking the concept of power as a precipitator of empowerment, many authors have their views. The authors below saw "Power" as the capacity of some persons and organizations to produce intended, foreseen and unforeseen effects on others ${ }^{[6,7]}$. According to these two sources, the class-dominated nature of our society means that, a small number of people have vast economic or political power, while the majority have little or none. Therefore, to uphold power in society, the conventional rule is that, only few people or groups should wield power and many people or most groups should be powerless. "Powerlessness" can be understood as expectations of a person that, his/her own actions will be ineffective in influencing the outcome of life events ${ }^{[8,9]}$.

Empowerment may therefore be understood in different contexts by different people due to geographical, cultural, economic, social, environmental and technological backgrounds. According to UNDP, empowerment to people could mean the variables of self-strength, gaining control, self-power, self-reliance, and right of choice and life of dignity ${ }^{[10]}$. All these variables could take on individuals, groups and an entire community orientation. Gaining access to these variables may depict power and control over livelihood indicators such as choice, freedom, decision-making, and socio-economic autonomy.

Again, gaining access to these variables may also mean attempting to manage their available resources to reduce poverty, make formal and informal institutions accountable for their actions and inactions. Therefore in the words of Perry, "the outcome of empowerment is to bring about changes in attitudes and opinions over a period of time" ${ }^{[11]}$. What is debatable is whether these changes in attitudes and opinions should always be positive? In other words, if people are taken through processes which turn them violent and destructive, could that be empowerment? Perhaps, this paper may find answers to that as events unfold.

Moreover, empowerment and personal control are synonymous. For instance, two authors, agree that, "empowerment" acquisition improves likelihood of people to control their own lives since they understand their own needs better than anyone else ${ }^{[5,12]}$. People should therefore be empowered to control their own lives. Empowerment therefore featured in the Millennium Development Goals as number 3 "promote gender equality and empower women". In the current Sustainable Development Goals, critical scrutiny depicts that, empowerment runs through close to half of the goals (SDGs 1, 4, 5, 8, 10, 16, 17).

\section{Objectives of the Study}

The study aims at achieving the following:

1. To identify the various approaches to empowerment.

2. To ascertain the association between empowerment and some socio-economic aspects of human life.

3. To identify the challenges to the empowerment of women.

\section{Methodology}

The study was a systematic review of literature based on empowerment dynamics across different disciplines.

\section{Search Strategy}

The online databases EBSCO Host, Science Direct, Wiley online, JSTOR, Taylor and Francis were used. The search terms were "Approaches" AND "Empowerment" AND "Women" AND "Community" AND "Health".

The inclusion and exclusion criteria were set. The inclusion criteria were all articles relating directly to contribution of social protection interventions. About 38 articles and documents were downloaded based on abstract and content analysis in relation to the study objectives. However about 34 articles and documents satisfied the inclusion criteria. 


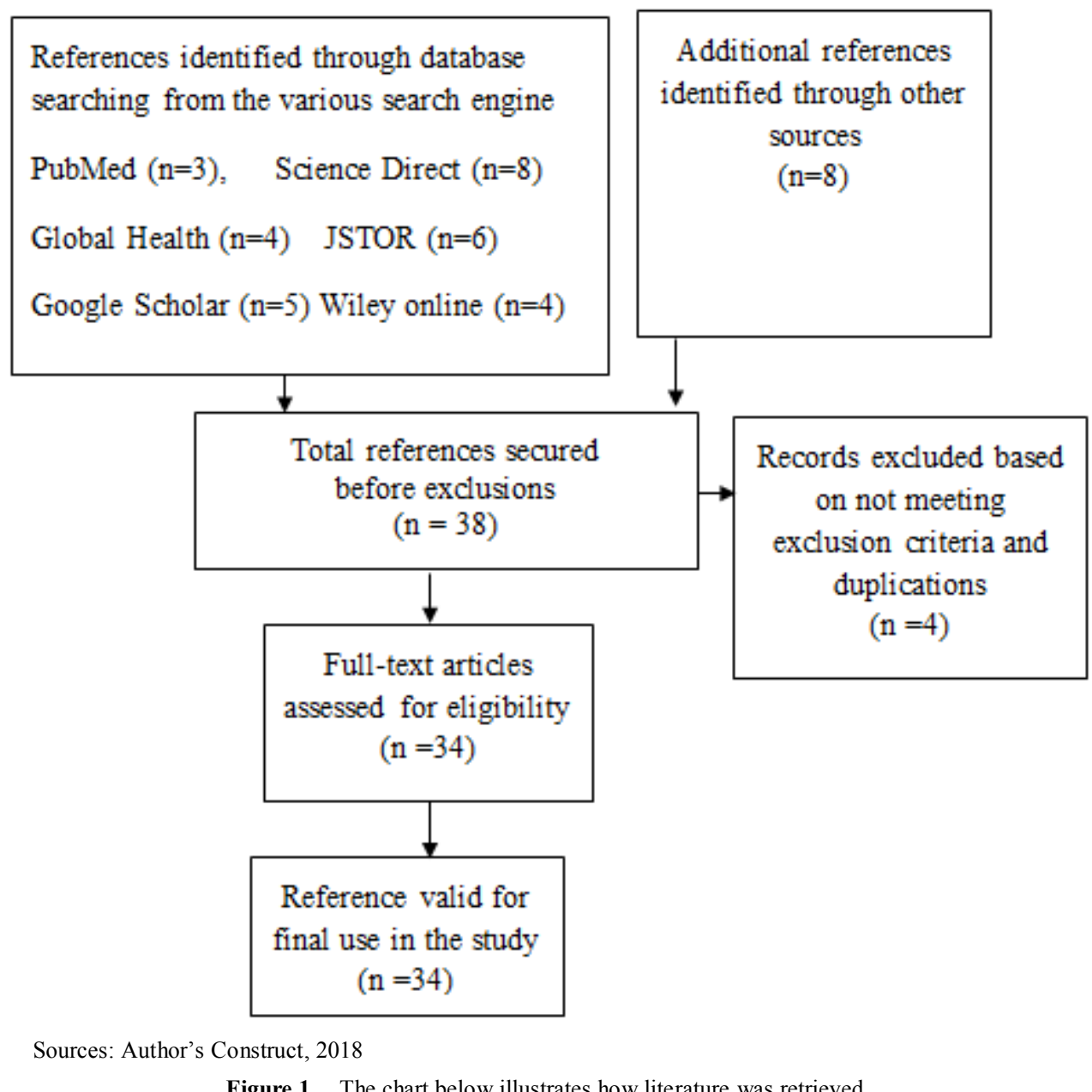

\section{Theoretical Framework}

The theory underpinning the study is the Middle Range Theory of Community Empowerment. This Theory of Community Empowerment (TCE) was developed by Cynthia Armstrong Persily and Eugenie Hildebrandt to encourage communities to increase their knowledge, capacity and decision making skills ${ }^{[13,14]}$. Hildebrandt had used the Community Involvement in Health model to improve community participation in some African communities. According to Hildebrandt, empowerment was an effective way to nurture participation. The two authors developed the TCE and propagated it. The authors had stated that, empowerment has many definitions and depending on the context, it can be a contested concept. The authors as health professionals, however understood community empowerment as "when the health care professional shares control with the community to make members effective managers of their own health"

\section{Conceptual Framework}

The study adopted the conceptual framework by the National Opinion Research Centre (NORC) in 2010 developed for the U.S. Department of Health and Human
Services as illustrated below.

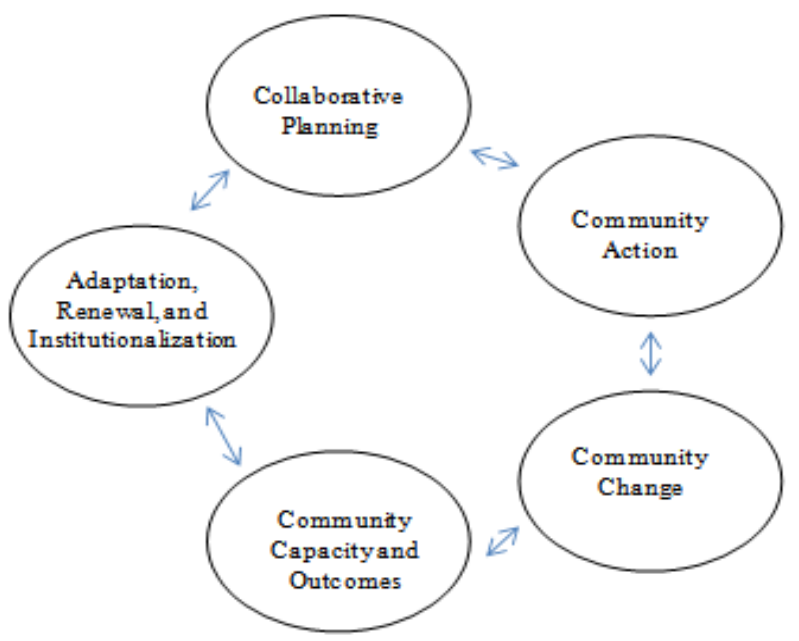

Source: Adopted from the National Opinion Research Centre (NORC), 2010

Figure 2. Conceptual Framework of Sustainability of Community Coalition through Empowerment

The conceptual framework above has the strength of internal reinforcement. Each stage within the circle has both backward and forward interactions and influences. 
For instance, community action may result in community change and a change in community can also result in action by the community. Again, a community change has an association with community capacity and outcomes and the reverse is also true ${ }^{[15]}$. This conceptual frame work therefore identifies how researchers, policy makers and practitioners have defined and measured sustainability for community coalitions through empowerment. The conceptual framework is appropriate since the ultimate result of empowerment will be to develop and ensure sustainability.

\section{Foundation of Empowerment}

Many scholars have done some works on empowerment. One such scholar is Professor Amartya Sen, an eminent economist. The economist wrote about empowerment through his Concept of Capability Approach (CA) ${ }^{[16,17,18 \text {, }}$ 19]. The concept of capability approach sentenced on the people's freedom to achieve well-being and opportunities to do what they value. Again, the writings of Andrea Cornwall on "Women's Empowerment: What Works"? A feminist perspective has also been one of the recent additions to the foundation of empowerment. The author viewed empowerment as an "unfolding process of changes in consciousness and collective power" ${ }^{[20 .}$ pp 343].

Again from a different perspective, John Rawls emphasized self-respect and access to primary goods and services in his "theory of social justice" ${ }^{[21]}$. Self-respect comes about when one is empowered to gain knowledge and capacity in a phenomenon. Such empowerment can be self-dependent, having control over their own assets and taking major decisions. Perhaps both Rawls's theory and Sen's capability approach were inspired by the notable works of Berlin, who wrote about the Two Concepts of Liberty which advocated and heightened the positive signs of freedom ${ }^{[22]}$.

The international policy community may have been prompted by the works of Basic Needs Approach (BNA) to take a second look at "empowerment" "[23,24,25]. The current paper is focused on how "empowerment" is used across different discplines and further re-positions the word empowerment deeply in particular disciplines of women and community health.

\section{Approaches to Empowerment}

The approaches to empowerment relates to the socio-economic and politcal paradigms in a community. These various socio-economic and political paradigms discussed in relation to empowerment are empowerment and management orientations, empowerment and marginalised sets, empowerment and education and finally empowerment and community health, of which empowerment and women's health were briefly dealt with.

\section{Empowerment and Management Orientations}

In the management orientation, people needing empowerment are conceived in positions of powerlessness and domination. Therefore managers perceived empowerment as the use of certain procedures to convert those without power into equitable positions. It can be asserted that, empowerment and oppression are an inverse relationship. In organizations where empowerment is either minimal or non-existent, oppression reigns and vice-versa. Corroborating this, West asserted that, when people are powerless for some time, they realize that there is the need for an authentic identity to condemn the unauthentic tendencies, and the act of condemning the unauthentic tendencies is the process of empowerment ${ }^{[26]}$. For instance, West further contended that, according to theories of rationality, "people are both individuals and social beings and that the culture within which an individual lives must be seen by them to be "authentic" that is, consistent with their beliefs and values'.

\section{Empowerment and Politcal Dispensation}

In recent times, empowerment has been closely tied to the strings of politics. When people are thought to know their rights to vote, freedom of speech, right of choice and other entitlement, politicians deemed they have empowered the masses. Again empowerment has taken on other more tangible orientations such as provision of socio-economic amenities such as road construction, health facilities, educational facilities, security provisions, among others. The intangible empowerment variable may be in the form of skilled training through education, seminars and other capacity enhancing skills. The politicians believe when these variables are provided in society, members of the society are empowered to cater for themselves in an authentic environment. In much the same way, politicians who empower the community members through either tangible or intangible variables also pass through the process of empowerment in their political career, inferring from the ideas of Friedman, "political empowerment would seem to require a prior process of social empowerment through which effective participation in politics becomes possible" [27 pp34]. When social empowerment is high, minimal marginalization may be the result.

\section{Empowerment and Marginalised Sets}

Marginalization and empowerment are also in inverse relationship. Being marginalised means being side-lined. This situation may be due to sheer numbers of the group, not commanding any force to change the progression of a phenomena, incapacity of the group to erupt in any form due to ignorance, lack of role models, socio-cultural limitations, financial constraints and political oppression. When people are affected by any of these conditions of marginalization, they are powerless and need to be empowered. In most developing countries, vulnerable groups are marginalised in terms of their race, gender, age, religion, health status and social position. All categories of people with these variables are susceptible to 
marginalization, and any act of improving their lives in these variables is counted among the empowerment continuum. For instance, in the work of Solomon ${ }^{[3]}$, reference was made to the efforts of social work helping black people to identify their core values. This empowered the community of the black people to accomplish selfdetermined goals using their own rich available resources to complete some tasks such as education, improved health status, community development, co-ordination, among others.

\section{Empowerment and Education}

Tasks are accomplished with ease when people are empowered. One approach to empowerment is through formal and informal education. Empowerment is indistinguishably linked to education. Aside from education being a crucial part of all empowerment packages, it also acts as an empowerment process. For instance, education is crucial for people who are illiterate and the physically challenged such as the blind and the hearing impaired. When such categories of people like the hearing impaired are educated, they are empowered to communicate their ideas through the sign language. This empowering measure given to them propels them to interact with people who are not hearing impaired. Their ideas are noticed and respected in decision making within their families and communities. After going through this empowerment process, they are empowered to become productive to their economies. According to Courts, people who are illiterate are empowered to gain a sense of their own power as learners and "meaning makers" [28 pp148]. Education as an empowerment approach empowers both the individuals and groups (majority and minority). Another author, Al-Haj, builds on the assertion of Court ${ }^{[29]}$ that, education as an approach to empowerment can sometimes hold different empowerment potentials for different people, especially in situations of a dominant group and minority ${ }^{[30] .}$

Different schools of thought have emerged on the assertion that, empowerment can both refer to a fundamental change at the individual level and a more representational change at the communal level. Differing opinions on this assertion have been documented. For instance Griffin, has reiterated that, fundamental change at the level of the individual will be reflected in fundamental social change ${ }^{[31]}$.

In another scenario, empowering women in education is very important. The old dictum by Dr. Kwagyiri Aggrey that "when you educate a boy, you educate one individual, when you educate a girl you educate a nation" is still prominent. Again, available literature shows that, social interventions which provide women opportunities to better education and well-being have effects on many people since women keep the home and care for children. Empowering women in education is based on human rights and an essential instrument for attaining equality as echoed in the Beijing Platform for Action.

\section{Women Empowerment and Socio-economic Development}

\section{Women Empowerment and Gender Equality}

Empowering women is a part of the feminist stance. Feminist scholars have published that, a lot of women are subject to oppression by men especially in developing countries. This act of oppression by men has passed through time and emanates from the male-controlled tradition of some society's, especially in sub-Saharan Africa and the Arab world. The oppression covered physical violence, decision-making, sexual harassment, the workplace and the family related discrimination. In each of these situations, women resort to different coping and adaptation mechanisms and hence different empowerment strategies are necessary depending upon the issues at stake [32]

\section{Women Empowerment and Gender Parity Index}

Certain factors account for the need to empower women in our societies to promote socio-economic development. These factors go against women and result in gender disparity. Among such factors are sex disparity in schools, differences in completion rates at the basic level, fewer proportions of women in paid jobs, the representation of women in positions of higher order such as parliament and institutional heads. All these variables mentioned are not in favour of women because women make up smaller numbers. Again, poverty, economic growth and gender inequalities are closely linked to women's health (SDGs 1, $3,4,5)$. Women are empowered so as to secure gender equality. Gender disparities occur in different spheres of society, educational, economic, work and political spheres.

Empowering the political, social, economic status of women is recognized by the International Conference on Population and Development -ICPD ${ }^{[33] .}$ The conference realized that, women were discriminated on the basis of their gender and some of the measures were to empower women in health, nutrition and education right from the earlier stages in life. For instance, the need to empower women in the economic sector is displayed by occupational segregation, gender wage gaps, and smaller percentages of women in both paid and unpaid jobs.

\section{Women Empowerment and Reproductive Health}

Aside from the above, for women to realize their full potential, it was also advocated that, women be empowered to have full control of their reproductive rights. By this process of empowerment, women may have the right to a safe sex life and be able to decide issues relating to child birth. Some of these decisions that women should be empowered to take include inception of pregnancy (in-vitro fertilization or otherwise), child delivering intervals, the total number of children to deliver and the 
mode of delivery.

\section{Women Empowerment and Community Health}

The other aspect of women's empowerment is related to health status and its implication to community health. Globally, women are the key players in home management in addition to their formal and informal duties outside the home. These put a lot of physical, emotional, psychological and economic stresses on them and therefore they deserve quality health care ${ }^{[34]}$. While the developed countries have put up strong mechanisms for women's health, the opposite is practiced in developing countries, particularly among developing societies. A host of socio-cultural barriers have hindered empowerment processes leading to negative impacts on women's health status. The policy community has advocated for tactical health reforms to empower the lives of women. Despite these efforts, some factors still hinder the progress of women's empowerment and health status. Among these are, the existence of traditions, lack of formal education, child marriage, malnutrition, broken homes, religious affiliations, lack of social cohesion, and poor quality of health care, inadequate health care facilities, among others. These have contributed to the high children and maternal deaths which are recorded especially in developing countries ${ }^{[35,36,41] \text {. }}$

Admittedly, the health systems in developing countries are recently appreciating the role of women within community development efforts. It is therefore imperative that, women are empowered to improve their lives. Available literature attests to the fact that, the health systems in a country function more effectively if women are politically, socially and economically empowered.

\section{Challenges to Women's Empowerment}

Women's empowerment has faced a lot of bottlenecks particularly in developing countries. Many factors have been outlined to be responsible for this situation. Among such factors are family, community behaviour, culture, health care system, technology and some unfavourable state policies ${ }^{[34]}$.

The family influence the lives of women. Families with higher social status especially through education are empowered. However, in developing countries, literacy levels are very low and women are the most affected. Possible reasons for the low literacy levels for women may be due to cultural factors, poverty, child marriage, child labour and home care practices. All of these are negative practices that undermine the process of empowering women in our societies.

Again, the health care system is also an inhibiting factor to women's health. Among such inhibiting factors, are generally poor quality of care, the ineffectiveness of social protection interventions such as Health Insurance Systems, longer distances to access health services, among others. The ineffectiveness of all these factors undermines the women's empowerment process. Developing countries are therefore confronted with high rates of fertility, maternal mortality, infant mortality and morbidity in the midst of poverty ${ }^{[37,38,40]}$.

The community and state have virtually shared similar barriers to women's empowerment. Barriers imposed by the community play a primary role in opposing women's empowerment process. These include factors such as the gross contempt of girls' education, restricting the decision-making power and the mobility of women and misinterpreting religious teachings are some of the many community-instituted barriers. Most women are so vulnerable in the community and would need the might of the state institutions to empower them to be productive. However, the social support by some countries is very minimal or non-existent due to limited fiscal space. These have affected women's empowerment and most women, especially those who go through labour may either not survive or give birth to stillborn babies ${ }^{[39]}$.

\section{Conclusions}

The meaning of the word "empowerment" has been contested and has survived through the scrutiny of many scholars. Against satisfying a single discipline, the word empowerment has been conceptualised in context and made process oriented. Any time, a system is reinforced to function in the desired mode, that system has been empowered. Admittedly, the need for empowerment has been noted in gender inclination, individuals, and groups and even at the community level. The limitations to the empowerment process have been noted in developing countries and notably within developing societies. Among such limitations are the level of education raised earlier on, the limitedness of fiscal space, inefficient health systems, cultural, social and economic short falls. The impact of all these and our desire to inform policy demands the need to "re-examine empowerment in this era through the feminist lens".

\section{Policy Recommendations}

The study came out with few recommendations to inform policy as enumerated below:

1. The process of empowerment should not be conceived as pertaining to only the vulnerable. More often than not, some categories of people at the higher social status are also empowered through the need to adapt to technological changes.

2. The attention has always been on empowerment to the neglect of disempowerment. In as much as most people or institutions are vulnerable and empowerment is the yardstick, some categories of people or institutions are equally over empowered 
and their actions defeat human rights' principles. They have been the bourgeoisie and Lords who are not tempered with. Disempowerment is the option. Therefore policy has to be informed about the need to rethink disempowerment.

3. The social and cultural background of some sub-regions especially, African continent undermines most empowerment strategies adopted and there is the need to re-examine such factors. Such continents need more education and the need to give up some outmoded cultural and social practices.

4. International policy community should enforce the implementation of social protection floors (SPFs). A lot of countries signed up for the International Labour Organization (ILO) and the World Banks (WB) programme of social protection floors and should be urged to comply with what they signed as most of these countries have not implemented them Those countries which have implemented SPFs through the social protection interventions are not running the programmes effectively. These are programmes that actually highlight the need for empowerment and social protection interventions are the ideal tools for empowerment.

5. Safeguards for women in our societies are still not enough especially in developing countries. It is advocated that, women who are the major productive force in family upbringing, have a double burden of undertaking most home routine tasks and official duties should be protected in decision making and be empowered to realised their self-identity.

6. Informal services provided by women in the homes have to be factored as productive efforts and waged as part of domestic economic outcome.

\section{Areas for further Studies}

The study noted that, the need to assess the empowerment of women and the development of some recent social practices are overdue. These social practices are high rates of divorce cases, domestic violence, single parenthood, parental neglect, and child-labour, among others. The need to undertake a study to assess if women's empowerment has correlations with any of these variables will be laudable.

\section{Abbreviations}

$\begin{array}{ll}\text { BNA } & \text { Basic Needs Approach } \\ \text { CA } & \text { Capability Approach } \\ \text { ICPD } & \text { International Conference on } \\ & \text { Population and Development } \\ \text { HIS } & \text { Health Insurance Systems }\end{array}$

$\begin{array}{ll}\text { ILO } & \text { International Labour Organization } \\ \text { CAP } & \text { Community Access Program } \\ \text { MDGs } & \text { Millennium Development Goals } \\ \text { MRT } & \text { Middle Range Theory } \\ \text { NORC } & \text { National Opinion Research Centre } \\ \text { SPFs } & \text { Social Protection Floors } \\ \text { SDGs } & \text { Sustainable Development Goals } \\ \text { TCE } & \text { Theory of Community Empowerment } \\ \text { WB } & \text { World Bank } \\ \text { WHO } & \text { World Health Organization }\end{array}$

\section{REFERENCES}

[1] Lincoln, N. D., Travers. C., Ackers, P., \& Wilkinson, A. The meaning of empowerment: The inter-disciplinary etymology of $\mathrm{s}$ new management concept. International Journal Of Management, 1999; 3[6];1-33

[2] Lukes, S. [Ed] Power. Oxford: Blackwell, 1986

[3] Solomon, B. B., Empowerment: Social Work in Oppressed Communities. New York: Columbia University Press, 1976.

[4] Rappaport, J. Collaborating for Empowerment: Creating the language of mutual help. In H. Boyte \& F. Reissman (Eds). The New Populism: The politics of empowerment. Philadelphia: Temple University Press; 1986.

[5] Rappaport, J. Terms of empowerment/exemplars of prevention: Towards a theory for community psychology. America Journal of Community Psychology; 1987, 15(2): 121-148.

[6] Cornell Empowerment Group; 1986 p2 In Lord \& Hutchison. Process of Empowerment: Implication for Theory and Practice. Canadian Journal of Community Mental Health 12:1, Spring 1993, Pages 5-22

[7] Moscovitch, A. and Drover, G. Inequality: Essays on the political economy of social welfare. (1981). Toronto: University of Toronto Press.

[8] Asch, A. Will populism empower the disabled? Journal of Social Policy; 1986; 16(3): pp12-18.

[9] Keiffer, C. Citizen Empowerment: A developmental perspective. Journal of Prevention in Human Services, 1984; 3(16):9-35

[10] UNDP, Human Development Report; Gender and Development, 1995.

[11] Perry, H., L. The socio-economic impact of black political empowerment in a rural southern locality. Journal of Rural Sociology, 1980; 45(2): 207-222.

[12] Cochran, M. The parental empowerment process: Building on family strengths. In J. Harris (Ed.) Child psychology in action: Linking research and action. Brookline, MA: Croon Helm Publisher, 1986.

[13] Smith, M. J., Lierhr, P. R. Middle Range Theory for Nursing. New York: Springer Publishing Company; 2008 
[14] Hilderbrandt, E. Building Community Participation in Health Care: A model and Example. Journal of Nursing Scholarship, 1996; 28(2); 155-159

[15] National Opinion Research Centre (NORC). Assessing Sustainability of Community Coalition Post Federal Funding. United States Health Division; 2010.

[16] Sen, A. K., Commodities and Capabilities. Oxford: Elsevier Science Publishers; 1985

[17] Sen, A. K., Well-being, Agency and Freedom: the Dewey Lectures. Journal of Philosophy, 1985a; 82 (4): 169-221

[18] Sen, A. K., Development as Freedom. Oxford: Oxford University Press, 1999.

[19] Sen, A. K., Human Rights and Capabilities. Journal of Human Development, 2005, 6(2): 151-66

[20] Andrea C. Women's Empowerment: What Works? Journal of International Development. 2016; 28(3) 342-359

[21] Rawls J., A Theory of Social Justice, Oxford: Clarendon Press, 1971.

[22] Berlin, I., Two Concept of Liberty, In Berlin (1982) Four Essay on Liberty. Oxford: Oxford University Press, 1958.

[23] Stewart, F. Planning to Meet Basic Needs. London, Macmillan, 1985.

[24] Stewart, F. Women and Human Development: The Capabilities Approach by Martha C. Nussbaum. Journal of International Development. 2001; 13(8): 191-2

[25] Streeten, P. Basic needs: Some Unsettled Questions. World Development. 1984; 12(9): 973-8

[26] West, D. Authenticity and Empowerment: A Theory of Liberation. Harvester Wheatsheaf: Hemel Hempstead; 1990.

[27] Friedmann, J. Empowerment: The Politics of Alternative Development. Blackwell: Cambridge, 1992 pp. 34

[28] Courts, P. L., Literacy and Empowerment: The Meaning Makers. New York: Bergin \& Garvey, 1991.

[29] Al-Haj, M. Education, Empowerment and Control: The Case of the Arabs in Israel. Albany: State University of New York Press, 1995
[30] Lincoln, Nicola Denham, Travers, Cheryl, Ackers, Peter, Wilkinson, Adrian: The Meaning of Empowerment: the interdisciplinary etymology of a new management concept; International Journal of Management Reviews, 1999: 3 (6): $1-33$

[31] Brookman, A., Morgen S. Women and the Politics of Empowerment. [Eds]. Philadelphia; University Press, 1988

[32] United Nations Population Information Network. Women, Empowerment and Health. International Conference on Population and Development, Cairo, Egypt: UN Population Fund, 1994

[33] Qureshi, N., Shaikh, B., T. Women's Empowerment and Health: the role of institutions of power in Pakistan. Eastern Mediterranean Health Journal, 2007; 3(6); 1-7

[34] Pitman, P. M., Gendered Experiences of Health Care. International Journal for Quality in Health Care, 1999; 11(5); 397-405

[35] WHO. World Health Report: Make every mother and child count. Geneva, 2005.

[36] Castrol, R. A study on maternal mortality in Mexico through a qualitative approached. Journal of Women's Health and Gender Based Medicine, 2000; 9 (6): 679-690

[37] Gadit, A. A., Out-of-Pocket Expenditure for depression among patients attending private community psychiatric clinics in Pakistan. Journal of Mental Health Policy and Economics. 2004; 7 (1): 23-28

[38] Fikree, F. F., Health Services Utilization for Perceived Post-partum Mobility among Poor Women living in Karachi. Social Sciences and Medicine. 2004; 59 (4): 681-694

[39] National Health Information System. Utilization of Public Health Facilities in Pakistan. Islamabad. Pakistan; Government of Pakistan, 2000.

[40] Andrea C., Jenny E. Beijing +2 Where now for Gender Equality? Institute of Development Studies Bulletin; 2015, 46(4); pp 1-8

[41] Manicom L., Walters, S. (Eds). Feminist Popular Education in Transnational Debates: Building Pedagogies of Possibility. New York, Palgrave Macmillan, 2012. 